\title{
The Global Impacts of Farm Policy Reforms in Organization for Economic Cooperation and Development Countries
}

\section{Mary E. Burfisher, Sherman Robinson and Karen Thierfelder}

Multilateral negotiations on agricultural trade liberalization will require World Trade Organization (WTO) members, including Organization for Cooperation and Development (OECD) countries, to improve market access and to reduce domestic support and export subsidies. In this paper, we analyze the effects of agricultural policy reform by three OECD members who are major economies in world agricultural trade-the United States, the European Union (EU), and Japan. We use a multi-country computable general equilibrium (CGE) model with detailed treatment of the agricultural trade and domestic policies in OECD countries. Our framework takes into account the differences in production impacts among traditional, commodity-linked production subsidies and other types of domestic subsidies that recently have become more important in countries' farm support programs. We capture the operational features of farm support programs, allowing some domestic subsidies to insulate producers from market price changes while treating other payments as fixed, lump sum subsidies. When domestic policies insulate producers from market price signals, they dampen production responses to market access reforms in the domestic economy and to reforms in both partner countries. We find that this linkage leads to dramatic reductions in a country's farm program costs when another country eliminates its support unilaterally. Given the links among domestic support programs in OECD countries, we also find that multilateral reform leads to smaller output adjustments than unilateral reform.

In the next section, we describe agricultural trade and domestic policies in the three countries, differentiating them by their treatment or "color" under the global trade rules of the WTO. Next, we describe how crop-linked subsidies and other types of domestic support policies can affect production. We then simulate agricultural policy reforms by the three countries, and discuss the effects on their agricultural production, trade, and farm program expenditures.

\section{OECD Farm Support Policies}

In all three countries, commodity support is achieved through a set of interrelated trade policies and domestic farm subsidies. The EU and Japan rely heavily on trade policies to help limit domestic supply and maintain guaranteed producer prices above world levels. The average, postUruguay Round bound agricultural tariffs of the EU and Japan are 41\% and 118\%, respectively. In contrast, the U.S. has a substantially lower average agricultural tariff rate of $7 \%$. ${ }^{1}$ The EU additionally provides export subsidies for cereals, dairy, beef, and other commodities. These subsidies are used to support fixed domestic producer prices, and vary with changes in market prices relative to the intervention prices. The export subsidies are rebated to traders to clear the domestic market of their purchases from farmers at the guaranteed prices.

The three countries' support agriculture with a variety of domestic instruments, including output subsidies, input subsidies, farm household income transfers, price support payments, and other minimally distorting payments which provide sector-wide support, such as extension and research. As shown in table 1, we link domestic subsidy data from the OECD's 2000 Producer Subsidy Equivalent (PSE) database with WTO notifications of domestic support. The Uruguay Round's Agreement on Agriculture (URAA) differentiated domestic subsidies according to their effects on production and trade: "amber box" policies directly subsidize production and influence production decisions; "blue box" policies distort production but are linked with supply constraints; "green box" policies cause minimal distortions. ${ }^{2}$ Given the classification of the OECD countries' policies by WTO color, we then model the corresponding production impact.

In 2000, domestic subsidy expenditures expressed as a share of the value of total agricultural production were $17 \%$ for both the EU and the U.S., and 6\% for Japan (OECD). ${ }^{3}$ As 
OECD countries have adopted alternative farm support programs, the "amber box" domestic subsidies subject to WTO limits have been reduced: we estimate them to be equal to one percent of the value of total agricultural production in the EU and Japan, and 9\% in the U.S. Since 1999, Japan has shifted its rice support into a deficiency payments program with acreage diversion that meets the eligibility criteria for a blue box exemption. The EU has linked much of its grains and oilseeds support to acreage set-aside requirements, making these payments eligible for a blue box exemption. The U.S. had shifted much of its support into green-box compliant Producer Flexibility Contract (PFC) payments.

However, since 1998, price support programs have become a more important component of domestic support in both the U.S. and Japan. U.S. expenditure on its loan deficiency payments program increased from about one-half billion dollars in 1998 to $\$ 7.5$ billion in 2000 as world prices declined; Japan spent $\$ 1.5$ billion on its deficiency payments in 2000. Price support payments accounted for $24 \%$ and $28 \%$, respectively, of the PSE's total U.S. and Japan farm program expenditures in 2000.

\section{Modeling the Effects of Domestic Subsidies on Agricultural Supply}

We develop a global CGE model to analyze agricultural policy reforms by the U.S., EU, and Japan. There are 16 countries or regions and 18 sectors in the model. Since we focus on agricultural policies, we include 9 primary agriculture sectors and 6 processed food sectors; the other sectors in the economy are broadly defined as natural resources, manufacturing, and services. ${ }^{4}$ There are five primary factors: skilled labor, unskilled labor, land, capital, and natural resources. Unskilled labor and capital are mobile across all sectors while skilled labor, land, and natural resources are specific to different subsets of sectors.

Domestic subsidy payments are either exogenous: per unit output subsidies, household income transfer payments, and other minimally distorting payments or endogenous: variable output subsidies and price support payments. In table 2 we describe how policies operate in the CGE model and the sectors to which they apply. Output subsidies, the standard tools of domestic farm support programs, are fixed ad valorem subsidies per unit of output. They change relative prices and shift resources toward production of the subsidized goods. ${ }^{5}$ Because output subsidies distort production decisions, they are amber-box programs under the terms of the URAA. The U.S. and the EU no longer provide a large share of their support through these types of subsidies, and they accounted for only 15\% of Japan's domestic support expenditures in 2000.

We assume household income transfer payments do not affect production decisions. Payments allow farmers complete flexibility in their choice of crop plantings, and are made regardless of the level of production or current prices. Household income transfers have become an important element of U.S. farm programs since PFCs were introduced in the 1996 FAIR Act. Eligible U.S. farmers are being paid fixed, declining, annual lump sum payments from 19962002.

The effect of income transfers on U.S. agricultural production is the subject of considerable debate. We assume that U.S. markets are efficient, and that higher farm household income has no effect on product prices or on the marginal returns to labor, land, or capital. The household transfer payments send no signals to producers through commodity markets, or through household decisions on labor participation, savings, and investment, to change farm production levels, or input or product mix.

Much of the growing literature on farm household transfer payments focuses on market failures that could cause the household to respond to an income transfer in ways that have direct effects on farm production. Rude, for example, describes farm debt constraints, resulting in an income transfer enabling farm investment and higher farm output than would have occurred in the absence of payments. Vercamman develops a model in which a lump sum income transfer can expand farm output when farm households face constraints in off-farm work hours or a wedge between borrowing and savings costs, or have bequest motives. 
While the theoretical models focus on market failures, the limited empirical evidence suggests that markets are relatively efficient in the context of U.S. agriculture. ${ }^{6}$ Gardner argues that the disappearance of the farm problem, evidenced by average U.S. farm household income now exceeding nonfarm household income, refutes the econometric evidence of incomplete markets and other market failures. Collender reports on the absence of a credit constraint in U.S. agriculture due to more cautious borrowing and cautious lending following the farm credit crisis of the 1980s. Mishra and Morehart find that U.S. farm households have increasingly diversified their investments to include more off-farm allocations, suggesting that they are equalizing rates of return across on- and off-farm investments.

Other minimally distorting payments are budget expenditures that have minimal links to production decisions and which satisfy WTO green box criteria. These programs include payments for land conservation and management, pest and disease control, infrastructure, and some disaster assistance. We account for these fiscal expenditures but assume they have no production effects.

We allow for endogenous farm programs, where applicable. We consider the EU compensatory payments to be a variable output subsidy. These subsidies are paid directly to producers of grains, oilseeds, protein crops, and some animals. Introduced in 1993, the compensatory payments were designed to compensate EU producers for declining guaranteed producer price levels. They influence the production decision because payment eligibility requires current production of supported products. Since the total payment is fixed, the rate per unit of output contracts (expands) when output expands (contracts). We link compensatory payments to a 10-percent land set-aside.

We allow endogenous price support payments to insulate producers from falling output prices by providing guaranteed floor prices. The domestic policies in the U.S., EU, and Japan offer different levels of insulation. In the U.S., deficiency loan rates support producer floor prices for grains and oilseeds, with payments to farmers increasing when market prices decline. Japan's new income stabilization program provides guaranteed producer prices for rice and other grains. Their deficiency payments adjust with changes in market prices. Japan's rice program requires a reduction of rice acreage, which can be diverted into other uses and is eligible for other commodity program benefits. When receiving price support payments, producers will not respond to market price changes until the prices rise above the targeted price; there is a range in which producers are insensitive to price changes, and a range in which they are fully exposed to market prices. In the EU, export subsidies are used to clear excess domestic supplies resulting from the EU's fixed intervention prices for grain, oilseeds, livestock, dairy, and processed sugar. The cost of these endogenous price support payments and export subsidies can change dramatically following a policy shock because there are no supply constraints in the programs.

\section{Scenarios}

We analyze a single experiment: full removal of all agricultural import barriers, amber and blue domestic subsidies, and export subsidies by the U.S., EU, and Japan. We then decompose this experiment by country with experiments in which the U.S., the EU and Japan undertake unilateral reforms. These are our main conclusions:

- Insulating producers from market prices weakens a country's production response to partners' reform. When producers face guaranteed floor prices in deficiency payments programs or intervention price programs, adjustments to reforms in partner countries occur primarily through changes in subsidy payments, rather than through production (table 3 ). For example, when the EU (Japan) eliminates its domestic support and trade restrictions in agriculture, U.S. price support payments decline by $85 \%$ (74\%) as demand from the EU (Japan) increases.

- Domestic agricultural policies are, to some extent, a response to market conditions created by distorting policies of other countries. One country's costs are affected dramatically by 
another's unilateral reform. This is especially so for the U.S. (table 4). The EU's farm program costs are less responsive, suggesting that its policies are mostly aimed at its domestic constituency rather than a reaction to global market conditions (table 5). Japan's farm program costs increase when the U.S. and EU reform, mainly because their reforms cause the world price of rice to decline.

- Multilateralism leads to a "softer landing" than unilateralism. In all three countries, domestic agricultural production contracts with unilateral reform. The adjustment is smaller when all three countries reform multilaterally, reflecting that each country's domestic policies are partly a response to subsidies in other countries. For example, the contractionary effects of U.S. unilateral reform on U.S. farm production are partially offset by the stimulating effects of EU and Japan reforms on U.S. production. This suggests that undertaking domestic reform in a multilateral context can reduce both the inefficiencies in one's own economy, as well as the world market distortions that provide a credible rationale for those domestic subsidies.

- Domestic price supports partially neutralize a county's reforms of its other "pillars." Market access has been argued to be the key element in global reform because domestic subsidy rates are relatively low and because open borders raise the costs of domestic price supports, creating pressures for their reform. However, continued OECD expenditure on programs that insulate producers from price signals suggest that the benefits of market access reforms may be relatively limited in the context of a partial or gradual reform process. Much of the debate over farm policy reform in the WTO has focused on the potential supply effects of decoupled programs. More attention should be given to the use of insulating price policies because they limit adjustments to and the potential benefits from global reform.

\section{References}

Collender, R. "Agricultural Boom and Bust: Will History Repeat in the 1990s?” Agriculture Outlook. April (1999): 22-26.

Cord, L. and Q. Wodon. Background Paper No. 7: Do Mexico's Agricultural Programs Alleviate Poverty? Unpublished, World Bank, Washington, DC, 1998.

Davis, B., A. deJanvry, E. Sadoulet and T. Diehl. "Policy Reforms and Poverty in the Mexican Ejido Sector." Policy Harmonization and Adjustment in the North American Agricultural and Food Industry. R. M.A. Loyns, Ronald Knutson, Karl Meilke and Antonio YunezNaude, eds. University of Guelph Press, 2000.

Gardner, B.L. “Changing Economic Perspectives on the Farm Problem,” J. Econ. Lit. 30 (1992): 62-101.

Japan, Ministry of Agriculture, Forestry and Fisheries. The Basic Law on Food, Agriculture and Rural Areas. Japan’s Agricultural Review. Vol. 29, 2000.

Lewis, J., S. Robinson and K. Thierfelder. "Free Trade Agreements and the SADC Economies." Discussion paper, IFPRI Trade and Macroeconomics Division, 2001.

Mishra, A. K. and M. J. Morehart. "Off-Farm Investment of Farm Households: A Logit Analysis.” Agricultural Finance Review, in press. 
Organization for Economic Cooperation and Development (OECD). Producer Subsidy Equivalent Database, 2001.

Rude, J. “Green Box Criteria: A Theoretical Assessment.” Agriculture and Agri-food Canada, Economic and Policy Analysis Directorate. Publication No. 2007/E. January, 2000.

Vercammen, J. “A Dynamic Analysis of Lump Sum Farm Subsidies,” paper presented at the joint Canadian Agricultural Economics Society/American Agricultural Economics Association annual meetings, Chicago, IL, 2001.

Walter-Jorgensen, A., and T. Vig Jensen. The Cap and the International Trade Negotiations. Ministeriet for Fodevarer, Landbrug og Fiskeri, Statens Jordbrugs-og Fiskeriokonomiske Institut, Copenhagen, 2001. 


\section{Footnotes}

Mary E. Burfisher is a Senior Economist at the Economic Research Service, U.S. Department of Agriculture, Sherman Robinson is the Director of the Trade and Macroeconomics Division, International Food Policy Research Institute, and Karen Thierfelder is an Associate Professor of Economics at the U.S. Naval Academy. We thank Praveen Dixit, C. Edwin Young, and John Dunmore for helpful reviews, and Ekaterina Krivonos for research assistance. The views expressed in this paper do not necessarily represent the views of the authors' respective institutions. 


\begin{tabular}{|c|c|c|c|c|c|c|c|c|c|}
\hline \multirow{3}{*}{$\begin{array}{l}\text { Behavior } \\
\text { in CGE } \\
\text { model } \\
\text { WTO } \\
\text { treatment }\end{array}$} & \multicolumn{3}{|c|}{ Output subsidy } & \multirow{3}{*}{$\begin{array}{l}\text { Input subsidy } \\
\text { Intermediate input } \\
\text { subsidy, fixed per } \\
\text { unit of input } \\
\text { Amber }\end{array}$} & \multirow{2}{*}{\multicolumn{2}{|c|}{$\begin{array}{l}\text { Farm household income transfer } \\
\text { Direct payment to household, fixed }\end{array}$}} & \multirow{2}{*}{\multicolumn{2}{|c|}{$\begin{array}{l}\text { Price support payment } \\
\text { Price subsidy, endogenous, fixed } \\
\text { producer price }\end{array}$}} & \multirow{3}{*}{$\begin{array}{l}\text { Other } \\
\text { Minimally distorting } \\
\text { Green }\end{array}$} \\
\hline & \multicolumn{2}{|c|}{$\begin{array}{l}\text { Output subsidy, fixed per } \\
\text { unit of output }\end{array}$} & \multirow{2}{*}{$\begin{array}{l}\begin{array}{l}\text { Variable } \\
\text { output } \\
\text { subsidy }\end{array} \\
\text { Blue }\end{array}$} & & & & & & \\
\hline & Amber & Blue & & & Green & Amber & Amber & Blue & \\
\hline $\mathrm{EU}$ & $\begin{array}{l}\text { Production } \\
\text { aid and } \\
\text { subsidies to } \\
\text { crops and } \\
\text { livestock, } \\
\text { interest } \\
\text { subsidies } \\
\end{array}$ & $\begin{array}{l}\text { Prod- } \\
\text { uction } \\
\text { aid for } \\
\text { peas, } \\
\text { beans }\end{array}$ & $\begin{array}{l}\text { Compen- } \\
\text { satory } \\
\text { payments, } \\
\text { set asides, } \\
\text { and } \\
\text { livestock } \\
\text { premiums } \\
\end{array}$ & $\begin{array}{l}\text { Production aid and } \\
\text { payments per } \\
\text { hectare for crops, } \\
\text { production aid for } \\
\text { livestock fodder, } \\
\text { silage }\end{array}$ & $\begin{array}{l}\text { Transitional payments } \\
\text { to Sweden, payments } \\
\text { for set-asides and } \\
\text { cessations, } \\
\text { conservation, income } \\
\text { aid }\end{array}$ & & & & $\begin{array}{l}\text { Land mgmt., organic farming, pest } \\
\text { and disease control, conservation, } \\
\text { farm improvement, agrotourism, } \\
\text { sub-national payments }\end{array}$ \\
\hline Japan & $\begin{array}{l}\text { Interest and } \\
\text { insurance } \\
\text { subsidies }\end{array}$ & & & & & & $\begin{array}{l}\text { Price } \\
\text { stabilization for } \\
\text { eggs, horticulture }\end{array}$ & $\begin{array}{l}\text { Price } \\
\text { stabilization } \\
\text { with supply } \\
\text { controls for } \\
\text { rice, soybeans, } \\
\text { milk } \\
\end{array}$ & $\begin{array}{l}\text { Extension, pest and disease } \\
\text { control, infrastructure, rice } \\
\text { diversion/environmental payments }\end{array}$ \\
\hline U.S. & & & & $\begin{array}{l}\text { Crop insurance, } \\
\text { input credit subsidy }\end{array}$ & $\begin{array}{l}\text { PFC, credit on assets, } \\
\text { income tax } \\
\text { concessions }\end{array}$ & $\begin{array}{l}\text { Market loss } \\
\text { assistance }\end{array}$ & $\begin{array}{l}\text { Loan deficiency } \\
\text { payments and } \\
\text { marketing loan } \\
\text { gains }\end{array}$ & & $\begin{array}{l}\text { Extension, conservation, } \\
\text { irrigation, emergency } \\
\text { conservation, farmland protection, } \\
\text { crop disaster }\end{array}$ \\
\hline
\end{tabular}




\begin{tabular}{|c|c|c|c|}
\hline & Countries and sectors & Production effects & Farm program costs $\stackrel{1}{-}$ \\
\hline $\begin{array}{l}\text { Output/input subsidies, fixed ad } \\
\text { valorem rates (with fixed input- } \\
\text { output coefficients) }\end{array}$ & $\begin{array}{l}\text { U.S.: wheat, other grains, oilseeds, other } \\
\text { crops, livestock, dairy, processed sugar } \\
\text { EU: wheat, other grains, oilseeds, } \\
\text { livestock, dairy, processed rice, processed } \\
\text { sugar } \\
\text { Japan: wheat, other grains, oilseeds, } \\
\text { Livestock, dairy, processed sugar }\end{array}$ & $\begin{array}{l}\text { Increase market returns by raising prices } \\
\text { or lowering input costs, resulting in } \\
\text { increases in output. Increased supply } \\
\text { reduces market prices, offsetting some of } \\
\text { the benefits of the subsidy. }\end{array}$ & $\begin{array}{l}\text { Subsidy costs increase (decrease) } \\
\text { when output increases (decreases) }\end{array}$ \\
\hline Variable output subsidy & $\begin{array}{l}\text { EU: wheat, other grains, oilseeds, other } \\
\text { crops, livestock, dairy, processed rice, } \\
\text { processed sugar }\end{array}$ & $\begin{array}{l}\text { Increase market returns but per unit } \\
\text { return declines as output increases, } \\
\text { eliminating any marginal incentives to } \\
\text { expand output. Land eligible for } \\
\text { payments remains in production of } \\
\text { grains and oilseeds. }\end{array}$ & $\begin{array}{l}\text { Subsidy costs do not change with } \\
\text { output or price changes. }\end{array}$ \\
\hline $\begin{array}{l}\text { Household income transfer } \\
\text { payment }\end{array}$ & $\begin{array}{l}\text { U.S. aggregate household } \\
\text { EU aggregate household }\end{array}$ & $\begin{array}{l}\text { Income transfers to household, with no } \\
\text { links to production decisions or prices. }\end{array}$ & $\begin{array}{l}\text { Subsidy costs do not change with } \\
\text { output or price changes. }\end{array}$ \\
\hline $\begin{array}{l}\text { Price support (price support } \\
\text { payment or export subsidy) }\end{array}$ & $\begin{array}{l}\text { US: price support payments to rice, wheat, } \\
\text { other grains, and oilseeds. } \\
\text { Japan: price support payments to rice } \\
\text { EU: export subsidies to wheat, other grain, } \\
\text { meat, dairy, and processed sugar }\end{array}$ & $\begin{array}{l}\text { Provide a guaranteed price floor for } \\
\text { producers. When market prices fall } \\
\text { below the floor, farmers are insulated } \\
\text { from market price signals. When market } \\
\text { prices rise above the floor, farmers } \\
\text { perceive and respond to market prices. }\end{array}$ & $\begin{array}{l}\text { Subsidy costs increase (decrease) } \\
\text { when market prices fall below (rise } \\
\text { above) the fixed, producer price. }\end{array}$ \\
\hline $\begin{array}{l}\text { Other, minimally distorting } \\
\text { expenditures }\end{array}$ & US., EU, and Japan & $\begin{array}{l}\text { May indirectly lower production costs } \\
\text { and expand output, but assumed in this } \\
\text { model to provide no price incentives to } \\
\text { producers. }\end{array}$ & $\begin{array}{l}\text { Program expenditures do not } \\
\text { change with output or price } \\
\text { changes. }\end{array}$ \\
\hline
\end{tabular}


Table 3 - Effects of agricultural policy reform on U.S., Japan and EU agriculture (\% change from base)

\begin{tabular}{|c|c|c|c|c|c|c|c|}
\hline Effects on countries: & $\begin{array}{l}\text { Total Farm } \\
\text { Program Costs }{ }^{1}\end{array}$ & $\begin{array}{l}\text { Variable } \\
\text { Program Costs }{ }^{2}\end{array}$ & $\begin{array}{l}\text { Farm \& Food } \\
\text { Output }\end{array}$ & Farm Output & Food Mfg. Output & $\begin{array}{l}\text { Farm \& Food } \\
\text { Exports }\end{array}$ & $\begin{array}{l}\text { Farm \& Food } \\
\text { Imports }\end{array}$ \\
\hline \multicolumn{8}{|l|}{ U.S. } \\
\hline All reform & -40.70 & -100.00 & -1.59 & -2.08 & -1.38 & 11.16 & 7.31 \\
\hline U.S. reforms & -40.70 & -100.00 & -2.88 & -4.08 & -2.34 & -1.14 & 8.12 \\
\hline Japan reforms & -19.83 & -73.62 & -0.60 & -0.90 & -0.46 & 5.87 & 0.66 \\
\hline EU reforms & -22.95 & -85.38 & -0.96 & -1.01 & -0.90 & 5.33 & 0.39 \\
\hline \multicolumn{8}{|l|}{ Japan } \\
\hline All reform & -72.19 & -100.00 & -2.31 & -6.21 & -1.21 & 7.83 & 42.45 \\
\hline U.S. reforms & 4.86 & 13.96 & -0.06 & 0.42 & -0.20 & 2.53 & 1.53 \\
\hline Japan reforms & -72.17 & -100.00 & -2.38 & -6.68 & -1.17 & 1.64 & 42.18 \\
\hline EU reforms & 4.06 & 11.22 & 0.06 & 0.67 & -0.11 & 3.86 & 0.29 \\
\hline \multicolumn{8}{|l|}{ EU } \\
\hline All reform & -85.25 & -100.00 & -6.01 & -7.68 & -5.27 & 4.03 & 31.07 \\
\hline U.S. reforms & -2.25 & -36.14 & -0.11 & -0.04 & -0.14 & 2.00 & 0.09 \\
\hline Japan reforms & -2.21 & -36.01 & 0.11 & 0.13 & 0.10 & 3.48 & -0.89 \\
\hline EU reforms & -85.25 & -100.00 & -6.53 & -8.34 & -5.73 & -1.80 & 31.43 \\
\hline
\end{tabular}

$\underline{1 /}$ Farm program costs include domestic subsidies and the EU's export subsidy expenditures for the agricultural sectors. We do not include agricultural tariff revenue.

2/ Variable program costs refer to U.S. and Japan price support payments and EU export subsidies. 
Table 4 - U.S. sectoral price support payments in response to policy reforms in other OECD countries (\$billion)

\begin{tabular}{|l|r|r|r|} 
& \multicolumn{1}{|c|}{ Base payment $^{\mathrm{a}}$} & \multicolumn{1}{|c|}{ EU reforms } & \multicolumn{1}{c|}{ Japan reforms } \\
\hline Rice & 0.65 & 0.49 & 0.48 \\
\hline Wheat & 1.74 & 0.68 & 0.93 \\
\hline Other grain & 6.89 & -2.45 & -1.36 \\
\hline Oilseed & 4.32 & 3.30 & 3.54 \\
\hline \multicolumn{2}{|l|}{${ }^{\mathrm{N}}$ Data for base payments are from OECD 2001 PSE database. } \\
\hline
\end{tabular}

Table 5 - EU sectoral export subsidy rates in response to policy reforms in other OECD countries

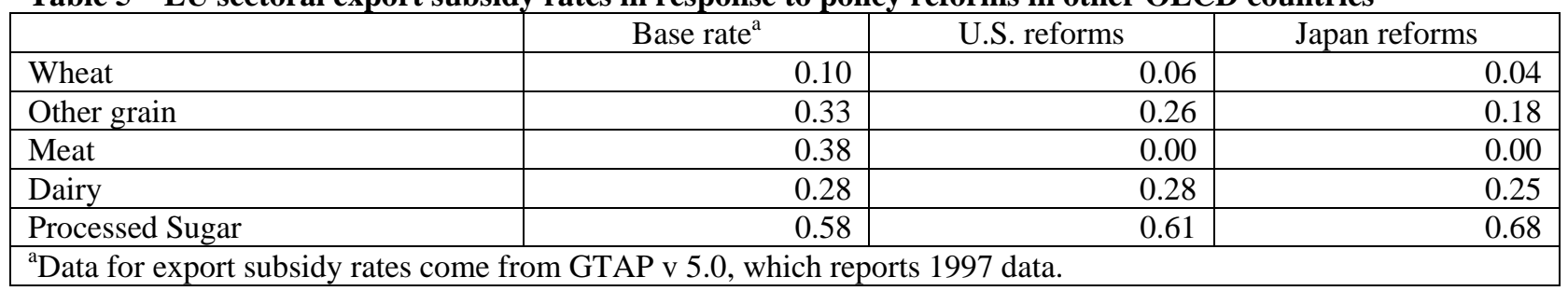




\footnotetext{
${ }^{1}$ Tariff data are from AMAD. The average agricultural rates are calculated as a simple average of tariffs by GTAP sector. They include over-quota tariffs of TRQ's and ad valorem equivalents of specific tariffs.

${ }^{2}$ The URAA placed expenditure limits on "amber box" policies; blue box polices are exempt from expenditure limits because they include a supply constraint and green box policies face no expenditure limits.

${ }^{3}$ For a detailed description of U.S. programs, see the electronic briefing room on farm and commodity policy at www.ers.usda.gov/briefing/. See WalterJorgensen, and Jensen for a description of EU farm policies. Japan's current policies are described in Japan, Ministry of Agriculture, Forestry and Fisheries.

${ }^{4}$ We use the standard global CGE model described in Lewis, Robinson, and Thierfelder. Our data are from GTAP version 5, which has a 1997 base. Domestic policy data were updated to 2000.

Since the production technology in the model uses fixed input-output coefficients for intermediate inputs, a subsidy to intermediate goods operates like an output subsidy, and we treat them identically.

${ }^{\mathbf{6}}$ In a developing country context, household income transfers are likely to have production effects. Mexico introduced household transfer payments in 1993 under the PROCAMPO program. Cord and Wodon and Davis, deJanvry, Sadoulet, and Diehl found large multiplier effects of PROCAMPO payments on household income, suggesting productive uses of the income transfers.
} 